\title{
THE INFLUENCE OF GEOINFORMATION SYSTEMS USING ON THE GEOGRAPHY PERCEPTION
}

\author{
Milan KUBIATKO; Kateřina MRÁZKOVÁ
}

\begin{abstract}
The using of geoinformation systems (GIS) in the geography teaching is becoming important aspect of the educational process, which support motivation, imagination and also success of pupils and students. The investigation was realized at the lower secondary school pupils and the main aim was to find out the influence of the GIS using in the geography lessons on the geography perception. As the other factors, which were analyzed, were gender and grade of study. The sample size was created by 348 pupils, 96 of them used GIS in the geography lesson and 252 not. As the statistical methods were used the determination of Cronbach's alpha coefficient for the reliability purpose and analysis of variance for the determination of the influence of selected factors on the geography perception
\end{abstract}

Key words: geoinformation systems, geography, lower secondary school pupils

\section{VLIV POUŽÍVANÍ GEOINFORMAČNÍCH SYSTÉMŮ NA VNÍMÁNÍ ZEMĚPISU}

Resumé: Využívaní geoinformačných systémů (GIS) ve vyučování zeměpisu se stává důležitým aspektem vzdělávání, který podporuje motivaci, představivost a v neposlední řadě i úspěšnost žáků a studentů. Výzkumné šetření bylo realizováno u žáků druhého stupně základních škol a mělo za cíl zjistit vliv použivání GIS v hodinách zeměpisu na vnímání zeměpisu jako vyučovacího předmětu. Jako další faktory, které vstupovaly do analýz, jsou gender a ročník studia. Celkově se zúčastnilo výzkumného šetření 348 žáků, přičemž u 96 z nich se v hodinách zeměpisu používaly GIS a u 252 ne. Ze statistických metod bylo použito Cronbachovo alfa pro stanovení reliability a analýza rozptylu na zjištění vlivu vybraných faktorů na vnímání zeměpisu.

Kličcová slova: geoinformační systémy, zeměpis, žáci druhého stupně základních škol

\section{1 Úvod}

Prezentovaná problematika patří do oblasti informačních a komunikačních technologií (ICT). Proto je na úvod nutné alespoň ve stručné podobě uvést obecné aspekty využití ICT ve výuce. ICT se dají využít ve všech fázích vyučovacího procesu, jako je motivace, zprrístupňování nového učiva nebo při opakování, v každém předmětu. ICT mají $\mathrm{v}$ rámci edukačního procesu mnoho výhod, jako je např́íklad zvýšení motivace či prezentace informací, které není možné zpř́stupnit jiným způsobem žákům a studentům. Právě jednou z možností, jak mohou ICT zvýšit efektivitu vyučovacího procesu a mít pozitivní vliv na motivaci, úspěšnost a vnímání studentů, je aplikace geografických informačních systémů (dále GIS). V našem př́ípadě je zájem mířen na to, zdali GIS dokáží změnit vnímání zeměpisu pozitivním směrem.

Zkoumání zájmu žáků o předmět zeměpis nepatří mezi častá výzkumná šetření, jak v domácím, tak i zahraničním prostředí. Souhrnně je možné uvést, že postoje respondentů k zeměpisu se pohybují od negativních přes neutrální $\mathrm{k}$ pozitivním $[1,2,3]$. Jak zlepšit postoje žáků $\mathrm{k}$ vyučovacím předmětům, nejenom $\mathrm{k}$ zeměpisu, se zaobíralo a zaobírá značné množství odborníků v dané oblasti. Jednou z možností, jak udělat zeměpis pro žáky prritažlivější a tím i zajímavější, nabízejí (GIS). Definic týkajících se GIS je značné množství. Jedna z mnohých, která nejlépe vystihuje jeho pojímání, je od Chrismana (1999) [4], který definuje GIS jako dynamický software, jehož hlavní oblastí využití ve školství je tvorba map, především tematických, jejich správa a jednoduchá aktualizace. Zároveň umožňuje každému, kdo v jeho prostředí dovede pracovat, provádět analýzy a vyhledávat informace z mapy, uložené v prostorových datech a databázích, které jsou základem pro tvorbu těchto map. Důvodů, proč zařadit GIS do výuky zeměpisu je, podobně jako definic, taky mnoho. Wiegand (2003) [5] vyzdvihuje zařazení geografických informačních 
systémů do výuky na základních a středních školách především proto, že nabízí žákům a studentům větší interaktivitu $\mathrm{v}$ porovnání s klasickými atlasy a pomáhají jim pochopit, jak číst, analyzovat a interpretovat mapu. Při práci $\mathrm{s}$ GIS mají studenti větší kontrolu nad tím, jak bude vypadat výsledná mapa, určují její formu, vybírají symboly a barvy. Mohou také určit, které vrstvy budou v mapě viditelné a které ne. GIS už ze své podstaty napomáhá osvojit si dovednosti čtení a analyzování mapy, usnadňuje interpretování mapy a zároveň podporuje rozvoj prostorového myšlení. Bednarzová a van der Schee (2006) [6] uvádějí tři hlavní důvody, proč učitelé používají GIS: (1) GIS podporují vyučování a učení se zeměpisu (geografii); (2) GIS jsou pomůckou k řešení geografických úloh na různé úrovni; (3) GIS jsou nevyhnutelným nástrojem pro svět v 21. století. Na druhou stranu existuje i řada překážek, které jsou pro učitele závažné a kvůli kterým GIS nebo jakékoli jiné geoinformační technologie nezařazují. Podle Demirciho (2008) [7] existují tři hlavní prŕíčiny, proč je tak málo aktivních uživatelů geoinformačních technologií: (1) učitelé neví, jak GIS používat; (2) nejsou si jisti, jak GIS zařadit do výuky a pocitují nedostatek kurikulárních materiálů; (3) nemají $\mathrm{k}$ dispozici prostředky na zakoupení a vybavení počítačů potřebným softwarem. Vlivem GIS na úroveň osvojení kartografických dovedností se zabývá řada výzkumů publikovaných od 2 . poloviny 90 . let 20. století. Geografické informační systémy totiž skrývají velký potenciál pro budoucnost geografie i zeměpisu jako vyučovacího předmětu na základních a středních školách. Jak dodávají van der Schee a Favier (2008) [8] GIS a ostatní geoinformační technologie nám umožňují objevovat svět lehčeji, rychleji a hlouběji.

Na GIS se není možné dívat jen jako na software typický pro vyučovací předmět zeměpis. Neoddělitelnou součástí GIS jsou kromě zeměpisu i kartografie, geodezie, matematika a informatika. Žádný z uvedených vědních oborů není možné vyčlenit, a také by nebylo vhodné dávat větši prostor některému $\mathrm{z}$ nich. Kdyby $\mathrm{k}$ tomu přece jen došlo, komplexnost GIS ztrácí na významu. Mylnou představou se stává předpona „geo“, která vyvolává zdání zařazení GIS k předmětu zeměpis. Uvedenou předponou je však vyjádřeno zpracovávání údajů, které jsou určitým způsobem vázané na geografickou polohu zkoumaného objektu. Proto údaje získané prostřednictvím GIS jsou využívány celou škálou předmětů, nejenom zeměpisem. Využití GIS v předmětu informatika je možné vidět ve sběru a zpracování získaných dat, tyto činnosti souvisí primárně $s$ uvedeným předmětem a ne se zeměpisem $[9,10]$. Právě práci s informacemi rozšiřuje u studentů schopnost správně pracovat s počítačem, student poznává význam sběru, trř́dění, ukládání a vzájemného propojování informací. GIS by měl pomoci studentům pochopit vzájemné souvislosti ve světě, což vede $\mathrm{k}$ úspěšnému zařazení do informační společnosti [11].

Dále jsou stručně nastíněna výzkumná šetření, která se zabývají zkoumání postojů $\mathrm{k}$ zeměpisu a to jak je ovlivňuje používání GIS. Např́iklad Artvinli (2009) [12] zjistil, že učitelé sice jsou otevřeni tomu, používat GIS ve vyučování zeměpisu, ale nemají dostatek vědomostí o používání uvedených zařízení, proto očekávají, že vládní instituce zabezpečí dostatek školení o používání GIS ve vyučování zeměpisu. Podobně se názorem učitelů na implementaci GIS zaobírají i Singh, Kleeman a Van Bergen (2012) [13] a stejně jako $v$ předešlé studii, tak uvedení autoři uvádějí, že učitelé nemají problém s akceptací GIS a jejich používaní ve vyučování geografie. Největší problém je však s nedostatkem školení, které by učitelé chtěli navštěvovat, aby dokázali používat GIS na úrovni, která je očekávaná. Yazici a Demirkaya (2011) [14] zkoumali vztah mezi používáním GIS a úspěšností u vysokoškolských studentů geografie. Pomocí korelačního koeficientu byl zjištěn pozitivní vztah mezi úspěšností a používáním GIS při vyučování. Podobný problém řešili ve své studii i Baker a White (2003) [15], když se prostřednictvím kváziexperimentálního designu snažili zjistit, zdali používání GIS má vliv na úspěšnost, a taky i na postoje. Do úvahy nebyl brán jenom zeměpis, ale všechny př́rodovědně zaměřené předměty. Autoři uvádějí pozitivní vliv GIS na postoje a úspěšnost. O pozitivním vlivu GIS na motivaci se učit se zmiňuje ve své studii West (2003) [16]. Kromě výše uvedeného má dle autora GIS ještě i vliv na lepší prostorové uvažování u žákủ. $O$ působení GIS na vědomosti a rozvoj kartografických dovedností pojednává i studie od Shina (2006) [17]. Autor na základě výsledků výzkumného šetření uvádí, že GIS pomáhá žákům při orientaci $\mathrm{v}$ mapách a taky, že při používání GIS zůstanou geografické vědomosti delší čas v paměti žáků.

Jak je zřejmé ze stručného přehledu literatury, která se týká vzájemného vlivu GIS a názoru na vyučovací předmět zeměpis, jsou prímo takto 
zaměřené výzkumné práce relativně vzácné. Studie se převážně týkají toho, jako učitelé hodnotí aplikaci GIS ve vyučování, př́padně co jim (učitelům) chybí při práci s GIS. Potom existují studie, kde jsou vzorkem studenti, či žáci a tam se autoři zaměřují na vliv GIS na úspěšnost studentů, či žáků v geografii. Dalším jevem, kterého si je možné všimnout, je, že téměř všechny práce jsou ze zahraničního prostředí, proto naše studie může alespoň částečně vyplnit mezeru v této výzkumné oblasti.

\section{Cíle a výzkumné otázky}

Hlavním cílem bylo zjistit, zdali se odlišují názory na zeměpis s ohledem na to, jestli jsou při vyučování zeměpisu použivány geoinformační systémy nebo ne. Hlavní cíl doplňovaly dílčí cíle, které zjišt'ovaly, zdali jsou rozdíly $\mathrm{v}$ názorech na zeměpis s ohledem na gender a ročník studia, za současného vlivu používání nebo nepoužívaní geoinformačních systémů.

$\mathrm{Na}$ základě výše zmíněného hlavního cíle a dílčích cílů byly formulovány následující výzkumné otázky:

1. Jaké jsou názory žáků na zeměpis $\mathrm{s}$ ohledem na to, zdali jsou využívány $\mathrm{v}$ hodinách zeměpisu geoinformační systémy nebo ne?

2. Existuje rozdíl $\mathrm{v}$ názorech na zeměpis mezi chlapci a dívkami za současného vlivu používání nebo nepouživaní geoinformačních systémů?

3. Má na názory na zeměpis vliv ročník studia za současného vlivu použivání nebo nepoužívaní geoinformačních systémů?

\section{Metodika}

\subsection{Respondenti}

Počet respondentů, kteří se zúčastnili výzkumu, byl 348 , z toho počet žáků, kteří používali ve vyučování zeměpisu geoinformační systémy, byl 96, zbytek tvořili žáci, kteří se s geoinformačními technologiemi nesetkali $(\mathrm{n}=252)$. Počet dívek byl o málo vyšší $(n=186)$ než počet chlapců. Nejvíce bylo žáků z 8. ročníku $(\mathrm{n}=107)$, potom následovali žáci z 9. ročníku $(\mathrm{n}=95)$, počet žáků ze sedmého ročníku byl 88 a nejmenší zastoupení měli nejmladší žáci $(\mathrm{n}=58)$. Průměrný věk respondentů 13.78 let.

\subsection{Výzkumný nástroj}

Jako výzkumný nástroj sloužil dotazník, který obsahoval 23 škalovaných položek Likertova typu s 5 body na škále (zcela nesouhlasím .... zcela souhlasím) s prostřední neutrální možností. Položky byly zaměřené na zjišt'ování postojů žáků $\mathrm{k}$ vyučovacímu předmětu zeměpis. Výzkumný nástroj dále obsahoval demografické položky, kde kromě otázky, zdali žáci používají na hodinách zeměpisu GIS nebo ne, byly otázky týkající se pohlaví respondentů a navštěvovaného ročníku.

\subsection{Administrace výzkumného nástroje}

Výzkumný nástroj byl administrován mezi žáky za asistence jednoho z výzkumníků. Ve tř́idě byla př́tomná i učitelka. Žáci byli obeznámeni s ćli výzkumu a ubezpečeni o anonymitě výzkumného šetření. Vyplňování dotazníků nepřesáhlo 15 minut a všechny dotazníky byly zařazeny do analýz.

\subsection{Analýza dat}

Po obdržení dotazníků byly odpovědi respondentů převedeny do číselné podoby. Při škálovaných položkách v pozitivním významu bylo použito kódování: zcela nesouhlasím - 1; spíše nesouhlasím - 2; nevím - 3; spíše souhlasím - 4; zcela souhlasím -5 . Př́i položkách v negativním významu bylo kódování obrácené. Po překódovaní položek byla určena spolehlivost výzkumného nástroje prostřednictvím Cronbachovo alfa $(\alpha=0.87)$, které indikuje vysokou spolehlivost výzkumného nástroje. Pro stanovení konstruktové validity výzkumného nástroje byla použita explorativní faktorová analýza, která rozdělila dotazník do třech dimenzí. Protože se faktorová analýza primárně týká zeměpisu, její další výsledky považujeme za nedůležité $\mathrm{s}$ ohledem na charakter časopisu. Pro splnění cílů a zodpovězení výzkumných otázek byly použity metody deskriptivní (průměr) a induktivní statistiky (analýza rozptylu).

\section{Výsledky}

Celkově je možné říct, že postoje žáků $\mathrm{k}$ zeměpisu jsou relativně pozitivní $(\mathrm{x}=3.55)$. Př̀i zjištování vlivu používání GIS na postoje k zeměpisu nebyl zjištěn významný rozdíl mezi žáky, kteří GIS použivali na hodinách zeměpisu a mezi těmi, kteří neměli možnost ho používat ( $F$ $=0.48 ; p=0.49$ ). Jak je možné vidět na grafu 1 , sice rozdíl nebyl významný, tak žáci, kteř́i použivali GIS, vnímali zeměpis pozitivněji $(\mathrm{x}=$ 3.59) než žáci, kteři neměli možnost používat GIS ( $\mathrm{x}=3.53)$.

Graf 1 Postoj k zeměpisu s ohledem na používaní GIS v hodinách zeměpisu 


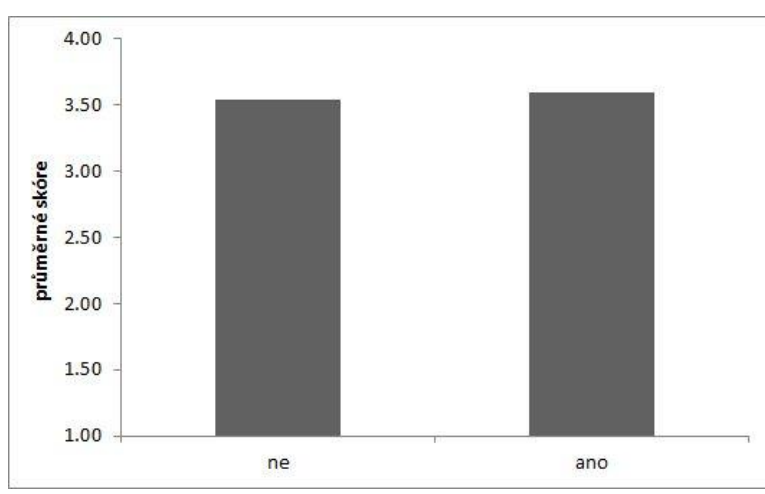

Při zjištování rozdílů mezi chlapci a dívkami $\mathrm{v}$ postojích $\mathrm{k}$ zeměpisu za současného vlivu používání GIS byl zjištěn významný rozdíl $(\mathrm{F}=$ $4.61 ; \mathrm{p}<0.05)$. Jak je zobrazeno $\mathrm{v}$ grafu 2 , dívky, které nepoužívaly GIS, vnímaly zeměpis pozitivněji $(\mathrm{x}=3.57)$ v porovnání $\mathrm{s}$ dívkami, které GIS používaly $(\mathrm{x}=3.46)$. U chlapců byla situace odlišná, ti co nepoužívali GIS v hodinách zeměpisu, měli $\mathrm{k}$ tomuto předmětu měně pozitivní postoje $(\mathrm{x}=3.49)$, jako chlapci, kteří se s GIS aktivně setkávali v hodinách zeměpisu $(\mathrm{x}=$ 3.73).

Graf 2 Postoje k zeměpisu s ohledem na gender za současného vlivu používaní GIS

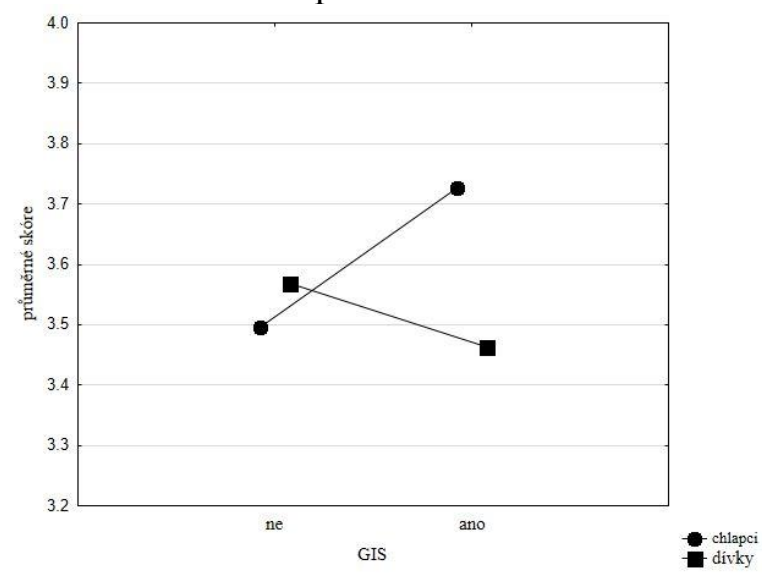

Při zjišstování rozdílů $\mathrm{v}$ postojích $\mathrm{k}$ zeměpisu, $\mathrm{s}$ ohledem na navštěvovaný ročník za současného vlivu používaní GIS, nebyl zjištěn významný rozdíl $(\mathrm{F}=1.31 ; \mathrm{p}=0.27)$. Jak je zřejmé $\mathrm{z}$ grafu 3 , výsledky nebyly konzistentní. U žáků 7-ho a 8ho ročníku došlo k tomu, že postoje se staly méně pozitivní, když byl používaný GIS. U žáků 6-ho a 9-ho ročníku byl trend opačný. Při použivání GIS se postoje stávaly pozitivnějšími. Nejvýraznější rozdíl ve skóre byl pozorován u nejstarších respondentů. Pro lepší přehled je skóre uvedeno v tabulce 1.
Graf 3 Postoje k zeměpisu s ohledem na ročník za současného vlivu používaní GIS

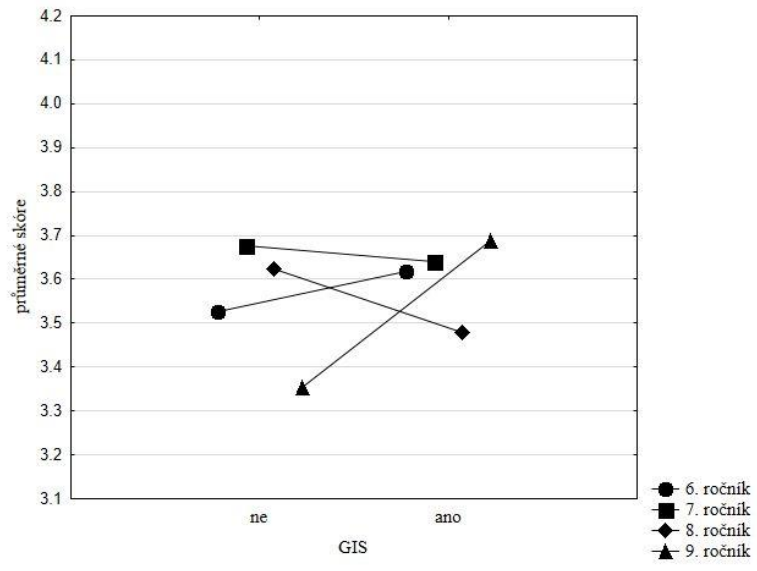

Tabulka 1 Průměrné skóre s ohledem na ročník za současného vlivu používaní GIS

\begin{tabular}{|c|c|c|}
\hline ročník & používání GIS & skóre \\
\hline 6 & ne & 3.52 \\
\hline 6 & ano & 3.62 \\
\hline 7 & ne & 3.67 \\
\hline 7 & ano & 3.64 \\
\hline 8 & ne & 3.62 \\
\hline 8 & ano & 3.48 \\
\hline 9 & ne & 3.35 \\
\hline 9 & ano & 3.69 \\
\hline
\end{tabular}

\section{Diskuze a závěr}

Cílem studie bylo zjistit, zdali používání GIS ve vyučování zeměpisu má vliv na postoje žáků základních škol $\mathrm{k}$ uvedenému předmětu. Jako výzkumný nástroj byl použit dotazník s položkami Likertova typu. Postoje k zeměpisu byly relativně pozitivní, a to i když se porovnávaly postoje $\mathrm{k}$ uvedenému předmětu u skupiny respondentů, kteři použivali GIS v hodinách zeměpisu i u těch, kteří ho nepoužívali. Respondenti, kteří používali GIS, vnímali zeměpis o málo pozitivněji, než druhá skupina respondentů. Vychází to $z$ toho, že GIS, jak je uvedeno $v$ mnohých literárních zdrojích, působí motivačně na žáky a také může zlepšit vnímání předmětů $[16,18]$.

Zkoumáním dalších dvou proměnných (gender a navštěvovaný ročník) byly zjištěny zajímavé výsledky. U chlapců dle očekávání vzrostl zájem o předmět zeměpis, pokud byly aplikovány do vyučovacího procesu GIS. U děvčat naopak došlo k poklesu zájmů o uvedený předmět, když byly do vyučovacího procesu zakomponovány GIS. Důvodů, proč tomu tak je, je vícero. Jednou 
z klasických prŕičin je větší zájem o technické věci u chlapců v porovnání s dívkami. Tento fakt je často zmiňován v mnoha výzkumných studiích [19], tedy že dívky ve většině prrípadů nemají rády technické věci v porovnání $\mathrm{s}$ chlapci. $\mathrm{S}$ tím může souviset $\mathrm{i}$ fakt, že $\mathrm{v}$ př́ípadě aplikace GIS do výuky zeměpisu jejich zájem o tenhle předmět bud' zůstává stejný, nebo klesá. Na rozdíl od chlapců, kde dochází $\mathrm{k}$ zvýšenému zájmu o daný předmět. Pravděpodobně chlapci neberou GIS jako nutnost, ale jako obohacení hodiny, které jim umožňuje lépe pochopit daný předmět a slouží i jako nástroj, který jim daný předmět více přibližuje, lépe mu chápou a taky je pro ně zajímavější. Další možností, proč zájem o zeměpis při aplikaci GIS výrazně stoupá u chlapců v porovnání s dívkami, nabízí studie od autorů Subrahmanyam a Greenfield (1994) [20], kteř́ hovoří, že software založený

na prostorovém vnímání, což je v našem př́padě GIS, má pozitivnější vliv na chlapce, na dívky o mnoho menší. Možná je to jeden z faktorů, proč chlapci vnímají zeměpis při aplikaci GIS pozitivněji v porovnání s dívkami.

Při zjišt’ování rozdílů na základě navštěvovaného ročníku vznikly nekonzistentní výsledky. Jestliže u nejmladších a nejstarších žáků má GIS pozitivní efekt na vnímání zeměpisu, tak u žáků sedmého a osmého ročníku má negativní vliv na vnímání daného předmětu. Jak je vidět, není možné aplikovat tvrzení, že nejstarší žáci většinou vnímají předmět nejméně pozitivně [3]. GIS pravděpodobně působí na nejmladší žáky $\mathrm{z}$ důvodu, že jeho aplikace možná ještě není na profesionální úrovni. Nejmladší žáci využívají ve většině prŕípadů GIS jako zábavu, což může způsobovat jejich zvýšený zájem o předmět. U starších ročníků dochází již pravděpodobně $\mathrm{k}$ aplikaci GIS na takové úrovni, jak je vyžadováno, proto se to nemusí vždy shodovat s představami žáků. Ti to berou jako úkol navíc, proto může docházet $\mathrm{k}$ poklesu zájmu o předmět. Uvedená studie se snažila alespoň částečně vyplnit chybějící mezeru ve výzkumné oblasti týkající se GIS a to, zdali jeho aplikace do vyučovacího procesu má pozitivní vliv. Nabízí se mnoho výzkumných možností, existuje značné množství výzkumných nástrojů zaměřených na vnímání GIS, které po jejich přeložení do češtiny mohou být použity ve výzkumu. Také je možné přidat další proměnné, které mohou ukázat jaký má GIS vliv na vzdělávání. Jak již naznačuje studie, GIS má velký potenciál a při jeho správné aplikaci je možné zvýšit zájem o předmět. Proto je to jedna z cest, jak zlepšit vnímání předmětů a taky efektivitu vzdělávání.

\section{Literatura}

[1] BROOK, D. L. Students' attitudes towards geography. Journal of Social Studies Research. 1977, Volume 1, No. 2, pp. 60-69. ISSN 0885985X

[2] MCTEER, J. H. High school students' attitudes toward geography. Journal of Geography. 1979, Volume 78, No. 2, pp. 55-56. ISSN 0022-1341

[3] KUBIATKO, M., K. MRAZKOVA a T. JANKO. Czech student attitudes towards geography. Journal of Geography. 2012, Volume 111, No. 2, pp. 67-75. ISSN 0022-1341

[4] CHRISMAN, N. R. What does GIS mean? Transactions in GIS. 1999, Volume 3, No. 2, pp. 175-186. ISSN 1361-1682

[5] WIEGAND, P. School students' understanding of chloropleth maps: Evidence from collaborative, mapmaking using GIS. Journal of Geography. 2003, Volume 102, No. 6, pp. 234-242. ISSN 0022-1341

[6] BEDNARZ, S. W. a J. VAN DER SCHEE. Europe and the United States: the implementation of geographic information systems in secondary education in two contexts. Technology, Pedagogy and Education. 2006, Volume 10, No. 2, pp. 191-205. ISSN 1475-939X

[7] DEMIRCI, A. Evaluating the implementation and effectiveness of GIS-Based application in secondary school geography lessons. American Journal of Applied Sciences. 2008, Volume 5, No. 3, pp. 169-178. ISSN 1546-9239

[8] VAN DER SCHEE, J. a T. FAVIER. Beyond the map. Thinking through geography using maps viewers. 2008 In Paper presented at the Herodot Conference, Liverpool.

[9] SUDOLSKÁ, M. Geografické informačné systémy. In. 2. celoštátna konferencia INFOVEK 2001. 2001, online http://www.infovek.sk/archiv webu/konferencia/2001/zbornik/sudolska.html

[10] HORBAJ, P. Základné informácie o GIS a GPS a niektoré možnosti ich využívania (2). AT \& P Journal. 2005, ročník 12, číslo $8,5 \mathrm{~s}$ (online). ISSN 1336-5010

[11] SUDOLSKÁ, M. Úloha geografických infromačných systémov vo výchove študentov stredných a základných škôl. In Zbornik prispevkov GIS 2005. Zvolen: Technická Univerzita vo Zvolene, 2006, s. 152-160. ISBN 80-228-1581-0

[12] ARTVINLI, E. Approaches of geography teachers to geographical information systems 
(GIS). Balikesir University Journal of Social Sciences Institute. 2009, Volume 12, No. 22, pp. 40-57. ISSN 1301-5265

[13] SINGH, S. S. B., G. KLEEMAN a P. VAN BERGEN. Opportunities to implement GIS in teaching and learning geography: A survey among smart schools in Sabah, Malaysia. Procedia - Social and Behavioral Sciences. 2012, Volume 69, No. 1, pp. 884-889. ISSN 1877-0428 [14] YAZICI, H. a H. DEMIRKAYA. Undergraduate geography studentsattitudes toward GIS. World Applied Sciences Journal. 2011, Volume 12, No. 11, pp. 2061-2067. ISSN 1818-4952

[15] BAKER, T. R. a S. H. WHITE. The effects of G.I.S. on students' attitudes, self-efficacy, and achievement in middle school science classrooms. Journal of Geography. 2003, Volume 102, No. 6, pp. 243-254. ISSN 00221341

[16] WEST, B. A. Student attitudes and the impact of GIS on thinking skills and motivation. Journal of Geography. 2003, Volume 102, No. 6, pp. 267-274. ISSN 0022-1341

[17] SHIN, E. Using geographic information system (GIS) to improve fourth graders geographic content knowledge and map skills. Journal of Geography. 2006, Volume 105, No. 3, pp. 109-120. ISSN 0022-1341

[18] BEDNARZ, S. W. Geographic information systems: a tool to support geography and environmental education? GeoJournal, 2004, Volume 60, No. 2, pp. 191-199. ISSN 0343-2521

[19] AZUBUIKE, O. C. Influential factors affecting the attitude of students towards vocational/technical subjects in secondary schools in southeastern Nigeria. Journal of Educational and Social Research. 2011, Volume 1, No. 2, pp. 49-56. ISSN 2240-0524

[20] SUBRAHMANYAM, K. a P. M. GREENFIELD. Effect of video game practice on spatial skills in girls and boys. Journal of Applied Developmental Psychology. 1994, Volume 15, No. 1, pp.13-32. ISSN 0193-3973

PaedDr. Milan Kubiatko, PhD.

Institut výzkumu školy a zdraví

Pedagogická fakulta MU

Poříč́i 31a

60300 Brno, ČR

Tel: +420 549494885

E-mail: mkubiatko@gmail.com

Www pracoviště: katedry.ped.muni.cz/ivsz 